\title{
Examination of Prestigious Mass-Housing Identity via The Slogans: Cases in Izmir, Turkey
}

\author{
Oğuzcan Nazmi Kuru ${ }^{1}$, Fatma İpek Ek $\odot 2$ \\ ${ }^{1}$ Faculty of Architecture, Department of Architecture, Yaşar University, Izmir, Turkey. (Principal contact for editorial \\ correspondence), Email: 19400006002@stu.yasar.edu.tr \\ ${ }^{2}$ Asst. Prof. Dr., Faculty of Architecture, Department of Architecture, Yaşar University, Izmir, Turkey. Email: \\ ipek.ek@yasar.edu.tr
}

\begin{abstract}
Purpose

The paper aims to make a critical examination of the current prestigious mass-housing projects through the promotional slogans to understand the relationships between the promotional and architectural strategies.

Design/Methodology/Approach

In the research, the archive-based surveys were conducted by utilizing the framework of the case study method. The data were collected from the websites and electronic catalogues of the cases and analysed comparatively to reveal the messages given by the promotions and manifested in the architectural formations.

Findings

The study makes categorizations for the slogans and architectural services of the cases, and proposes that the promotional and architectural identities of the projects refer to a template that provides the sale guarantee, and therefore, cannot be broken easily to present the alternative living manners.

Research Limitations/Implications

The study is limited with the 20 similar-scale projects with independent sections of more than 50 households, addressing to the high-income level with the prestigious or luxurious qualities, and built, used, or under construction in the period covering 2015-2021, in Izmir city-centre and peripheries.

Social/Practical Implications

In social respect, the findings point out the common interdisciplinary genes creating the templates of the consumer society by manifesting that the high price is related to the services provided within the housing settlement but not the quality of architectural solutions.

Originality/Value

The paper tries to uncover the possible effects of the slogans in shaping the mass-housing identity for the high-income level, and reveal the close relationship between the consumer society and promotion of architecture, which results in selling housing projects at high prices with the same promotional and architectural templates.
\end{abstract}

Keywords: Architectural identity, consumption, housing slogans, mass-housing, promotional strategies 


\section{INTRODUCTION ${ }^{1}$}

Housing projects constitute the most dynamic, intense, and controversial area of design in architecture, and are always in demand naturally. The meaning of the housing is formed by the images, and associations taking place in our personal or social memory (Öymen Gür, 2000). Architectural typologies, design qualities, constructional solutions, affordability problems, urban considerations, and social interactions continuously shape and/or transform the identity of local housing, and in turn, are shaped by those ever-transforming housing identities. This almost organic reflection between housing and society keeps the discussions on the agenda of architecture, urban design, politics, and economics of countries, and redefines the roles of the parties. Changing expectations of the inhabitants are effective as strong as the regulations designed by the local governments (Bilgin, 1996). It is majorly the inhabitants' tendencies to set the rules in housing design, which converts the inhabitants into indirect designers of their housing. The role of the architect becomes limited by the ready-made designs of the housing templates which are frequently applied in almost every typology to fulfil the inhabitants' expectations, without risking the sales guarantee (Bilgin, 1994). Accordingly, housing becomes a product/commodity, the inhabitant becomes the consumer/buyer, and the architect turns into a producer/merchant in the mechanized understanding of the housing production (Bilgin, 2002; Özüerken, 1996). In this framework, concerns about selling and promoting housing transform the act of design into a mechanism working with marketing strategies.

By focusing on the current mass-housing cases in Izmir, the study examines the relationships between the architectural design and promotional strategies of the so-called prestigious or luxurious projects addressing the high-income level, and thus, how the modern housing identity changes in line with the changing demands as reflected by the slogans. The cases cover the 20 mass-housing projects built and/or under construction, after 2015, in Izmir city-centre and peripheries. In this framework, how the living and designing manners in the consumer society change the residential identity fundamentally constitutes the critical base at the theoretical background of the study. While selecting the cases, isolated, in other words, gated sites were preferred to narrow the scope of research. All cases serve for residential use; however, in the mixed-use projects, only the parts having residential use were examined. In terms of the scale, the projects with independent sections of more than 50 households were chosen.

The common descriptive keywords for every case were decided to be prestigious and luxurious as the qualitative limitation. The projects indicate overtly or covertly the same label of prestigious or luxurious in the promotional descriptions. The qualities of being prestigious or luxurious have been and will be transformed continuously under the changing tendencies of the society and technologies, however, the consumption culture will always create the most desired object to label it
1 An extended and comprehensive version of this article is available in Chapters 2, 3, and 4 of the master's thesis "Effects of Marketing Strategies on Prestigious Housing Identity: a Study on Mass-Housing Examples in Izmir City Center," presented to the Yaşar University (Kuru, 2021). 
as prestigious or luxurious, and to sell it to sustain. In the process until now, the acceleration of globalization dynamics and the universalization of new consumer goods and patterns in media have also played an active role in the housing sector of Turkey (Keyder, 2006). Within this respect, the manifold meanings of mass-housing and prestigious/luxurious housing in a local culture reflect the identity of the local society per se. Therefore, to comprehend the housing identity of local culture, we may begin with the analyses on the meanings referring to this identity.

\section{MASS-HOUSING AND PRESTIGIOUS HOUSING AS THE TERMS CONSTRUCTING THE CURRENT RESIDENTIAL IDENTITY}

The mass-housing projects have been increasing in quantity, in Turkey, since the enactment of the Mass-Housing Law in 1984; but especially after the 1990s, the living quality could gain importance in the housing sector (Sey, 1994). The qualities of affordability, the minimized duration of construction, and structural safety have resulted in a gradual increase in users' demands for this housing typology. The served qualities have always been varied in terms of the spatial program-although the architectural qualities have been limited with the ordinary through the mass-housing history (Bilgin, 1994; Sey, 1984). The mass-housing projects still correspond to the majority of user-demands, but currently, those projects are generally planned as the gated communities in the periphery of the city centre equipped with the facilities in the sites to meet the personal and social needs of the inhabitants. Especially, the projects designed for the high-income groups fulfil more needs of the inhabitants, which explains the increase in the prices-though these needs are also questionable. As generally recognized, the non-residential areas should meet the biological, social, and psychological needs that people cannot fulfil inside the house (Es \& Akın, 2008), which, recently, also become relevant for the mass-housing projects of the high-income group. In addition to being a residence, mass-housing is a mass-produced product subject to the total-quality perception (Altaş Esin \& Özsoy, 1998). After being a global-scale commodity, the quality of mass-housing projects, therefore, has always been related to its capacity to fulfil the needs of its users-like the qualities of other commodities (Feigenbaum, 1991).

Mass-housing is defined by Hasol (2005) as "the term used to describe a large number of housing units built with social and physical infrastructure." According to the Dictionary of Urbanology Terms, "it is a large-scale housing and resettlement initiative that meets the housing needs of a large number of families, carried out by public or private organizations such as a housing association, housing development partnership or housing banks" (Keleş, 1998). On the other hand, in the Mass-housing Law in Turkey, the mass-housing is defined as follows:

"The whole of 750-1000 dwellings to be built in settlements with a land area of at least 15 hectares, which will be newly opened and at least 200 in places where the zoning plan was approved and ready for construction 
before the date the law came into force, and their common facilities and areas and workplaces" (Law No. 2487 dated 8.7.1981).

As a consequence of the consumption culture, by the end of the twentieth century, the mass-housing typology has been integrated with the conceptions of social segregation, and the gated communities emerged by this integration as a frequently applied mass-housing type addressing the homogeneous groups in the society (Blandy \& Lister, 2005). The gated communities gave rise to the concept of prestigious housing, and the concept of housing was converted into a commodity providing their buyers with prestige indicating social status in society (Blakely \& Snyder, 1997). It refers to an identity produced for a homogenous high-income group, and the sustainability of this identity is guaranteed by the level of luxury.

Therefore, the phenomenon of luxury has always been at the top of the design criteria in the housing sector (Nicolae et al., 2009), as it points out the economic conditions of its buyers, and as the most important criterion constructing the social identity (Lee \& Young, 1996). The luxury providing prestige has become a housing quality per se, which needs to be examined conceptually, as the middle-income group has reached the economic freedom to care about the quality of their lives (Berry, 1994). The high-income groups in every society have always the opportunity to choose their lifestyles, therefore, there has always been a quality of living environment and preference suitable for them. The concept of luxury developing day by day, by gaining different meanings (Chuon et al., 2017) has turned into an image, and also crystallized in line with the preferences of middle-income level recently. However, regarding the current tendencies, it seems that the concept of luxury generally refers to a level that is minorly higher than the economic flexibilities of income groups.

In Turkey, the luxury residences are categorized regarding the opportunities offered by the gated communities-which, as a housing typology firstly seen in Istanbul, have been transformed through time regarding the user demands of especially the upper- and middle-income groups. These opportunities are shaped by the users' expectations about their income status and psycho-social identity (Nicolae et al., 2009). The housing design qualities, in this sense, are also defined by the expectations as manifested in details and material qualities in the architectural scale, and the settlement design in the urban scale. The facilities and social environment provided by the concept of luxury, in turn, determine the expectations of the users and make these expectations reflect on the residential spaces themselves by also shaping the contemporary housing identity. The spatial characteristics are supported by the architectural qualities of the projects which are also the indicators of the users' demands for luxury housing and for supporting their psychological and social identities with a certain level of living standard in the urban environment (Kwan et al., 2004). 
The label of prestigious for the high-income gated-community projects in Turkey is attached generally by regarding the size, whether there are additional rooms/spaces/components with special functions, smart technologies, technical structure, security systems, landscape design, social facilities, materials, workmanship, and resistance for earthquakes. That is, as status indicators when we examine the architectural features of the gated communities for the high-income group, the qualities leading to the consumption of the luxury comprise especially the mentioned functional, technological, and psychological aspects, which can be summarized in a list as follows:

1. Additional rooms/spaces/components with special functions: a.) parents' bathroom (although this space continues to be a common spatial property in all high-income projects as an indicator of the changing lifestyle, they have ceased to be an attractive feature); b.) laundry room; c.) cellar; d.) Turkish bath; e.) ironing room; f.) specially designed kitchen; g.) decorated circulation area; h.) windows up to the ground to enlarge the viewing capacity; i.) ergonomic quality; j.) aesthetic quality with odour and ambient vibrations.

2. Smart technologies and technical structure to control the apartment facilities both at home and outside: a.) the hot water service provided by solar energy systems that convert sunlight into electricity; b.) air conditioning/climatic infrastructure used with heating and cooling systems; c.) floor-heating systems, which is also to prevent visual pollution because of the air conditioners under the windows; d.) shutter systems with different adjustments regarding each window type; e.) water purification systems; f.) smart lighting; g.) acoustic quality; h.) technological equipment for energy saving.

3. $7 / 24$ security systems: a.) high-level security on site with visibleinvisible systems; b.) camera viewing screens; c.) alarm devices; d.) security walls around the residences; e.) 24-hour security guards.

4. Landscapes designed by landscape architects: a.) the integration between nature and gated housing units by the way of large terraces and gardens designed as living flora; b.) water elements and ornamental pools; c.) recreation areas; d.) urban furniture for recreation and resting; e.) no leftover spaces between the building blocks.

5. Social facilities: a.) the social spaces functionally designed to support the social activities; b.) privileges in residential sites to serve facilities in higher standards; c.) an outdoor swimming pool of specified size; d.) tennis courts; e.) running and walking tracks; f.) bicycle paths; g.) children's playgrounds; h.) sports fields of various sizes and numbers; i.) garage and parking lots; j.) indoor social facilities in the basements of the housing or in different building masses: indoor swimming pool, fitness centre, Turkish bath, and sauna, etc.; k.) the gastronomic facilities: cafes and restaurants; 1.) health services.

6. Materials and workmanship: a.) use of high-quality materials in applications; b.) use of high-quality equipment in interior spaces; c.) the high-quality workmanship. 
7. Resistance for earthquakes (especially after the 1999 earthquake, constructional problems were given more importance in Turkey, and the housing projects were designed following the renewed earthquake regulations): a.) strength of structures; b.) strength of ground with meticulous ground studies; c.) ground improvement by the method called jet grout or by piling under the columns in the foundation, in case the floor does not have the desired strength.

Regarding the current promotional strategies of the luxurious projects, it is the lifestyle, after all, that is marketed and consumed as an integral part of the design package highlighting the high-quality residential services and products. The luxury residences provide prestigious lifestyles to the users with a rich variety of facilities as the indicators of the users' social and economic statuses (Özgüven, 2008). However, the cultural, psychological, and physiological conditions of the users also play determining roles in indoor environment quality (Fabi et al., 2012). In this sense, living in prestigious residences and districts provides psychological satisfaction for the inhabitants as well as providing a peaceful life in a homogeneous society, even in the city centre, yet away from the crowds. The mass-housing turns into an expression of belonging to a prestigious class, and the prestigious envelope has the power of manipulating the psychology of the high-income user positively, which can be associated with the consequences of the consumer society.

\section{PRESTIGE IN THE CONSUMER SOCIETY}

Consumption as the very seminal concept shaping the "dynamics in human history" (Bocock, 1993) has resulted in not only quantitative but also qualitative changes. However, modern society generally has negative connotations, which may be associated with the adverse perspectives of the capitalist dynamics of Modernization leading to the consumption of identities at the end of the twentieth century. As referring to the societal mechanisms, its definition has complex layers: the consumption phenomenon is explained as an effect that initiates production to meet the needs of the society in the traditional sense, and also defined as an outcome in which the consuming individuals are guided by its economic, social and psychological effects (Featherstone, 2007).

Debord (2002) states that consumption becomes a lifestyle in our age. It subjugates both individuals and societies with its own rules and orientates individuals. Consumption has been in the process of transformation into a show day by day. Individuals, who are as if the captives of the modern world, think that they can reach happiness by simply consuming more in an ever-transforming mechanism providing them the ability to choose (Slater, 1997). However, in the current situation, it is very hard to explain the increase in consumption by only referring to the basic characteristics of the act of consuming; consumption is more than the sum of its components with its newly introduced symbolic identities. 

in Izmir, Turkey

Baudrillard (1998) defines the consumption pattern of the new form of society as a universal and consistent system of indicators created by certain rules and codes, of which aims are not related to providing basic needs of individuals through goods and services. In this system, needs and desires leave their places to social values and classifications. It points out the current associations between the living manners and the values of the used products, which, in turn, may transform the very living manner and even the taste into a commodity (Bourdieu, 1984).

In a similar perspective, Bocock (1993) defines consumption not only as a utility process but as a socio-cultural value process in which signs and symbols are also involved. Consumption emerges as a psychological, social, cultural, and economic reason, or a result of these reasons that support the development of the individual's sense of self in an individualization process (Bauman, 2000). Symbolic meanings, again, are attributed to consumption objects. While the consumption objects contribute to the formation of social classes with the benefits that they provide for the fulfilment of the needs and desires, they also serve as an indicator in the establishment of interactions between individuals by both the idea and act of consuming (Baudrillard, 2002).

Warde (1991) identifies consumption with communication between individuals, participation in social classes, and socialization concepts; it becomes a tool for these procedures. According to Kotler \& Keller (2006), socio-cultural and personal factors in the formation of consumer identity influence consumers' psychological interactions in the decision-making phase, and even, in buying and consuming procedures. Consumption, in this sense, emerges as an idea and action adopted by individuals in all areas of life (Baudrillard, 2002); hence, there have been historical, social, cultural, economic, and political events, and their consequences having connections with the dynamics of consumerism.

In this sense, housing as a social, cultural, and architectural entity has also been influenced by consumerism especially regarding its relationships with the served facilities and urban context. While undertaking the phenomenon of collective consumption of the 1970s, Urry (1995) points out the "spatial inequalities through sustaining much lower housing densities in richer areas" by referring to and neatly summarizing the related criticisms of Castells (1983), Dunleavy (1980), and Saunders (1990):

"It was argued that many services, especially housing, are not necessarily provided 'collectively' and can and should be privatised and individualised; that services are not necessarily 'urban' and as populations have undergone counter-urbanisation it has been realised that some of these can be located elsewhere; that what develops is a sociology of services which would have little to do with developing an 'urban' sociology; that the spatial distribution of activities is not to be regarded as determined by the social structure; and that the urban is in fact also crucially affected by changing relations of production, not just of collective consumption" (Urry, 1995). 
This widened critical lens focused on the 1970s consumption dynamics also helps us clarify today's identity of the housing environment. The spatial inequalities in the urban scale have been the consequences of the privatization of the services, which destroyed the collective logic of providing them in urban environments and caused counter-urbanization. Though this did not help the development of urban sociology, it paved the way for the emergence of the gated communities as an extreme version of privatizing collective consumption. The detachment of the collective consumption from the urban fabric has led to the attachment of facilities in satellite gated housing projects in the periphery of the city. This new attachment has become the prerequisite feature for the preference of segregated typologies. Therefore, while the accessibility was intentionally decreased by the detachment (from the urban), the concept of attainability emerged by the attachment (of the services), which, according to Pickvance (1985), is a consequence of spatial proximity as one of the three characteristics of the urban environment. The spatial proximity with the attainability of the services/facilities has been restructured in the gated communities and corresponded to the most important marketing strategy of today's housing identity.

In this sense, especially for the development of the current housing identity, the concept of marketing, after the consumer society, has played an important role in shaping this very identity, and set many of the rules even in architectural respect. The American Marketing Association (AMA) defined marketing in 1985 as follows: "Marketing is the activity, set of institutions, and processes for creating, communicating, delivering, and exchanging offerings that have value for customers, clients, partners, and society at large." Nevertheless, the segregated and gated communities are also the results of the marketing strategies, which aimed at dividing the society into homogeneous income levels to facilitate consumption procedures, as also stated by Willis (1990):

"The early history of marketing was precisely about separating consumer groups into socio-economic categories so that products could be aimed at them more exactly. Modern marketing, however, has moved on from delineating socio-economic groupings to exploring 'new' categories of lifestyle, life stage and shared denominations of interest and aspiration. This is a crucial move since it attempts to describe market segments not from an 'objective' point of view, but from the point of view of the consumer. Far from being the passive victim of commercialism's juggernaut, the consumer has progressively been recognised as having substantial and unpredictable decision-making power in the selection and use of cultural commodities."

Therefore, the scene of marketing in the modern age is set by the consumers' perspective by considering their lifestyles to provide them with further to be consumed. In this sense, leading the marketing strategies is about leading the consumers' changing demands. By following a Kantian tradition, Bourdieu (1984) allocates the flexibility of consumption to the wealthy segment: 
"The struggles to win everything which, in the social world, is of the order of belief, credit and discredit, perception and appreciation, knowledge and recognition-name, renown, prestige, honour, glory, authority, everything which constitutes symbolic power as a recognized poweralways concern the 'distinguished' possessors and the 'pretentious' challengers."

The signs of prestige or luxury are indispensable characteristics shaping today's housing market in Turkey. The changes in consumers' demands about obtaining prestige, especially, transform the identity of highincome mass-housing typology in architectural respect. Keeping the architectural pulse of the changing marketing strategies in the highincome mass-housing projects can only be possible by analysing the cases produced with the identities labelled as prestigious or luxurious. The promotional slogans and visuals may lead us safely in the way of such analysis.

\section{A READING OF THE RESIDENTIAL IDENTITY IN THE CONSUMER SOCIETY}

The architectural identity of the housing projects in the consumption society can also be analysed by examining the promotional representations of the projects. As it can be seen in all of the cultural products of a society, the dynamics and traces of that very culture crystalize in the architectonics of the housing projects, as well. The promotional representations of the housing projects, in that respect, reflect the ever-changing culture of the consumption society in their common architectural genes. Therefore, to understand these genes and the common qualities, the promotional representations in both visual and verbal contexts can be comparatively analysed and categorized. The rest of the paper attempts to undertake this examination by referring to the meanings of prestige and luxury as well as the consumption strategies in the housing market.

In the framework of the examination, the 20 mass-housing projects which have been implemented-or under construction-in Izmir city-centre and the periphery since 2015, and addressed to the high-income level inhabitants were selected as the cases to figure out the qualities related with the prestige or luxury. The settlement and constructional identifications of the cases are presented comparatively in Table 1 to introduce the projects regarding the common and differing contextual qualities and quantities. Furthermore, based on the promotional catalogues of the cases, the analyses were undertaken in 3 axes comprising 1) the comparative readings of the services and facilities provided in the housing settlements (Table 2), 2) the verbal and visual representations of the promotions based on the slogans and project images (Table 3), and 3) the semantic analysis of the slogans to uncover the direct and indirect messages (Table 4). 
Table 1. Contextual identities of the cases $^{2}$

\begin{tabular}{|c|c|c|c|c|c|c|c|}
\hline & 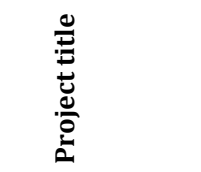 & 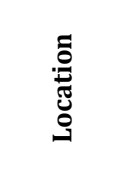 & 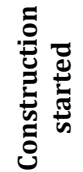 & 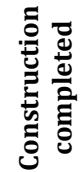 & 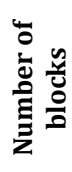 & 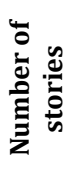 & 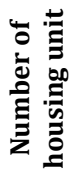 \\
\hline 1. & AllSancak & Konak & 2020 & $\begin{array}{l}\text { Dated } \\
2023\end{array}$ & 3 & 24 & 1069 \\
\hline 2. & Altın Orman & Bornova & 2017 & 2021 & 3 & 34 & 1215 \\
\hline 3. & Avcllar Effect & Bornova & 2015 & 2017 & 3 & 9 & 203 \\
\hline 4. & $\begin{array}{l}\text { Avcllar } \\
\text { Exclusive }\end{array}$ & Bayraklı & 2019 & 2021 & 2 & 10 & 104 \\
\hline 5. & $\begin{array}{l}\text { Avcllar } \\
\text { Prestige }\end{array}$ & Bornova & 2015 & 2017 & 2 & 8 & 270 \\
\hline 6. & Dap Kule İzmir & Bornova & 2017 & 2021 & 2 & 32 & 707 \\
\hline 7. & Folkart Incity & Bornova & 2017 & 2019 & 8 & 29 & 700 \\
\hline 8. & Folkart Life & Bornova & 2016 & 2018 & 8 & 15 & 830 \\
\hline 9. & Folkart Vega & Konak & 2018 & 2021 & 4 & 38 & 843 \\
\hline 10. & $\begin{array}{l}\text { Goldiva } \\
\text { Familya }\end{array}$ & Bornova & 2017 & 2020 & 3 & 14 & 328 \\
\hline 11. & İzka Port & Bayraklı & 2018 & 2020 & 1 & 34 & 144 \\
\hline 12. & $\begin{array}{l}\text { Mahall } \\
\text { Bomonti }\end{array}$ & Konak & 2016 & $\begin{array}{l}\text { Dated } \\
2022\end{array}$ & 12 & 58 & 466 \\
\hline 13. & Modda Suites & Bayraklı & 2018 & 2019 & 1 & 8 & 72 \\
\hline 14. & $\begin{array}{l}\text { My Way Deluxe } \\
\text { Alsancak }\end{array}$ & Konak & 2017 & 2020 & 1 & 8 & 111 \\
\hline 15. & Narova & Bornova & 2014 & 2019 & 2 & 6 & 114 \\
\hline 16. & $\begin{array}{l}\text { Narova } 3^{\text {rd }} \\
\text { Stage }\end{array}$ & Bornova & 2017 & 2019 & 2 & 7 & 124 \\
\hline 17. & $\begin{array}{l}\text { Narova } 4^{\text {th }} \\
\text { Stage }\end{array}$ & Bornova & 2017 & 2019 & 1 & 9 & 120 \\
\hline 18. & Ontan Bayraklı & Bayraklı & 2015 & 2016 & 1 & 18 & 259 \\
\hline 19. & Paradiso Buca & Buca & 2017 & 2019 & 1 & 18 & 60 \\
\hline 20. & $\begin{array}{l}\text { Teknoen } \\
\text { Altındağ }\end{array}$ & Bornova & 2017 & 2019 & 1 & 16 & 96 \\
\hline
\end{tabular}

In Table 2, the services and facilities of the 20 cases are given in almost a similar hierarchy in terms of their appearance orders in the promotional online catalogues/websites. That is, the images of the most preferred facilities/services are located on the front pages, while the images of less preferred facilities/services are located on the back pages. Besides, the numbers denote how often the related images are included in these catalogues. Accordingly, the facilities and services of outdoor swimming pool (60 times), café (23 times), fitness centre (15 times), site security (13 times), children's playground (13 times), car parking (12 times),
2 The information is taken from the online catalogues of the projects' websites. See consecutively AllSancak, 2021; Altın Orman, 2021; Avcllar Effect, 2021; Avclar Exclusive, 2021; Avclar Prestige, 2021; Dap Kule İzmir, 2021; Folkart Incity, 2021; Folkart Life, 2021; Folkart Vega, 2021; Goldiva Familya, 2021; İzka Port, 2021; Mahall Bomonti, 2021; Modda Suites, 2021; My Way Deluxe Alsancak, 2021; Narova 3rd Stage, 2021; Narova 4th Stage, 2021; Narova, 2021; Ontan Bayraklı, 2021; Paradiso Buca, 2021; Teknoen Altındağ, 2021. The visual and analytical data in all of the Tables in this paper are taken from these sources unless otherwise stated. 
sports fields (12 times) and indoor swimming pool (11 times) seem like the standards since they are provided most frequently and in more than half of the projects. The facility of the swimming pool-whether outdoor or indoor-appears 71 times in total, which demonstrates that the most highlighted part of the prestigious mass-housing identity mainly comprises the swimming service.

On the other hand, the visuals of the distinguishing features such as the sauna, LEED certificate, library, primary school, and pet hotel are either rarely encountered or only included verbally without any visual; thus, given at the end of the promotional information, which means that these facilities/services were added to the catalogues only to mention their existence as an attractive quality to increase the price. Nonetheless, the inclusion of, especially, the sauna, library, pet hotel, and primary school also corresponds to a question of use and needs to be answered by considering the real necessities of the users. The existence of a library containing an insufficient number of books and magazines may not contribute to the intellectual satisfaction of the inhabitants, and inevitably become useless over time.

On the other hand, in Table 3, the slogans in verbal respect, and the logos with the initial images at the catalogues in visual respect give clues about the general dispositions of the companies in housing design as well as the target audience and their expectations. When we look at the slogans especially, we can perceive that some basic and common qualities are frequently repeated in every expression. Regarding these qualities, a categorization based on the frequently mentioned terms may also be proposed to figure out the backbone dispositions forming the housing identity by the way of marketing strategies. These dispositions are coded with colours in the slogan column of Table 3: accordingly, the red is for the status words, the orange is for the experiences provided in the project, the purple is for the words targeting users' psychology, the blue is for the urban identity presented as a trademark, the green is for the financial connotations, and the grey is for the architectural approaches. These categories can be commented further as follows:

1. Status-based: the terms to highlight the social status gained by the prestigious/luxurious qualities provided in the project;

2. Experience-based: the terms to point out the new lifestyles or importance of the well-living experiences provided in the project;

3. Location-based: the terms to show the importance of being at the centre of the city in terms of the accessibility to the urban facilities as well as highlighting the urban identity of Izmir by implying its distinguishing geographical and natural qualities;

4. Psychology-based: the terms to manipulate the psychology of the potential users by implying the importance of their personal preferences;

5. Architecture-based: the terms to address the spatial qualities of the projects or the concepts of the projects; 
Table 2. Comparison of the services and facilities provided in the housing settlements with the frequencies of the related images in the catalogues ( 0 shows the facilities/services excluded visually from the catalogue/website though provided in the project)

\begin{tabular}{|c|c|c|c|c|c|c|c|c|c|c|c|c|c|c|c|c|c|c|c|c|c|}
\hline & 1 & 2 & 3 & 4 & 5 & 6 & 7 & 8 & 9 & $\begin{array}{l}\mathbf{1} \\
\mathbf{0}\end{array}$ & $\begin{array}{l}1 \\
1\end{array}$ & $\begin{array}{l}1 \\
2\end{array}$ & $\begin{array}{l}1 \\
3\end{array}$ & \begin{tabular}{|l|}
1 \\
4
\end{tabular} & $\begin{array}{l}1 \\
5\end{array}$ & $\begin{array}{l}1 \\
6\end{array}$ & $\begin{array}{l}1 \\
7\end{array}$ & $\begin{array}{l}1 \\
8\end{array}$ & \begin{tabular}{|l}
1 \\
9
\end{tabular} & $\begin{array}{l}2 \\
0\end{array}$ & \\
\hline 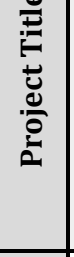 & 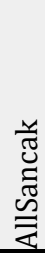 & 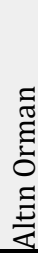 & 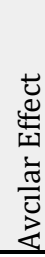 & 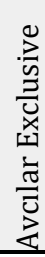 & 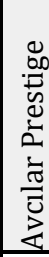 & 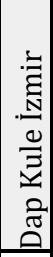 & 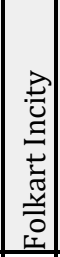 & 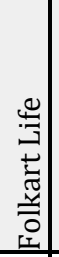 & 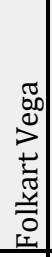 & 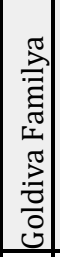 & 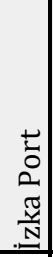 & 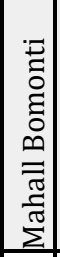 & 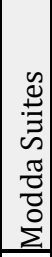 & 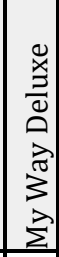 & \begin{tabular}{|c|} 
\\
\\
\\
\\
0 \\
0 \\
0 \\
$\frac{\pi}{z}$ \\
\end{tabular} & 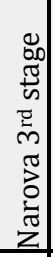 & 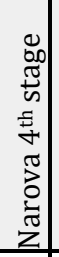 & 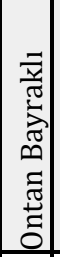 & 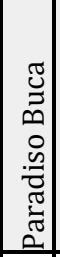 & 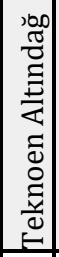 & $\begin{array}{l}\vec{E} \\
\stackrel{5}{\circ}\end{array}$ \\
\hline 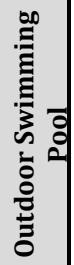 & 6 & 2 & 2 & 2 & 1 & 1 & 5 & 4 & 3 & 5 & 4 & 1 & 3 & 1 & 3 & 9 & 7 & 1 & & & $\begin{array}{l}6 \\
0\end{array}$ \\
\hline ๗ँँ & 3 & & 2 & 3 & 1 & & & 2 & 4 & & & 1 & & 3 & 1 & & & 1 & & 2 & $\begin{array}{l}2 \\
3\end{array}$ \\
\hline 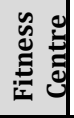 & 1 & 1 & . & 2 & 1 & 1 & 1 & 1 & 1 & 0 & 0 & 1 & . & . & 1 & 2 & 0 & 1 & 0 & 1 & $\begin{array}{l}1 \\
5\end{array}$ \\
\hline 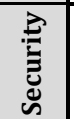 & 0 & 1 & 1 & 1 & 1 & 0 & 0 & 1 & 1 & 0 & 0 & 0 & 0 & 1 & 0 & 1 & 2 & 0 & 1 & 2 & $\begin{array}{l}1 \\
3\end{array}$ \\
\hline 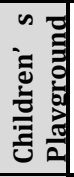 & 3 & 0 & & & & & 1 & 0 & 1 & 2 & & 1 & & & 1 & 1 & 2 & 1 & & & $\begin{array}{l}\mathbf{1} \\
\mathbf{3}\end{array}$ \\
\hline 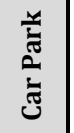 & 2 & 1 & 1 & 0 & 0 & 0 & 0 & 1 & 1 & 0 & 0 & 0 & 0 & 0 & 1 & 1 & 2 & 1 & 1 & 0 & $\begin{array}{l}1 \\
2\end{array}$ \\
\hline 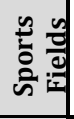 & 3 & 0 & & & & & 3 & & & 4 & & 1 & & & 1 & & & & & & $\begin{array}{l}1 \\
2\end{array}$ \\
\hline 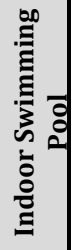 & & & & 1 & 2 & & 3 & 1 & 2 & & & & & & & & & 1 & & & $\begin{array}{l}1 \\
1\end{array}$ \\
\hline 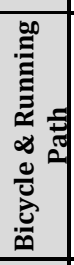 & & 0 & & & 0 & & 2 & 0 & & 3 & & & & & 0 & 2 & & & & & 9 \\
\hline$\overline{\bar{\pi}}$ & 2 & 1 & & 3 & & & & & & & & 1 & & & 1 & & & & & & 8 \\
\hline
\end{tabular}


Examination of Prestigious Mass-Housing Identity via The Slogans: Cases in Izmir, Turkey

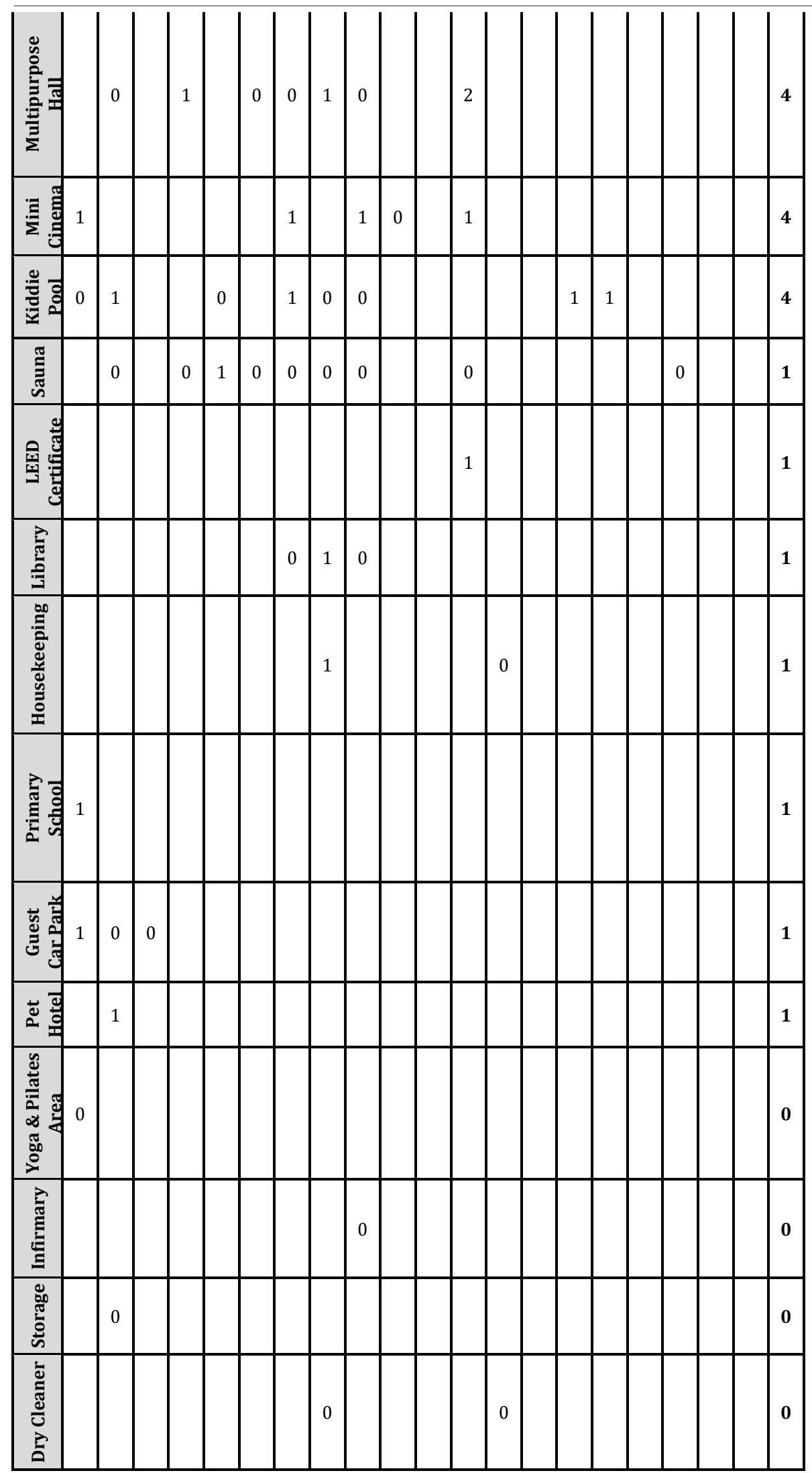


6. Finance-based: the terms to invite the potential users for saving and even earning money by the way of the project as an investment.

This categorization logic was also applied to the slogans by dividing these expressions, and coding the terms with colours regarding the directly or indirectly given messages in Table 4 .

Table 3. Comparison of the verbal and visual representations of the promotions based on the slogans and project images (slogans were translated from Turkish)

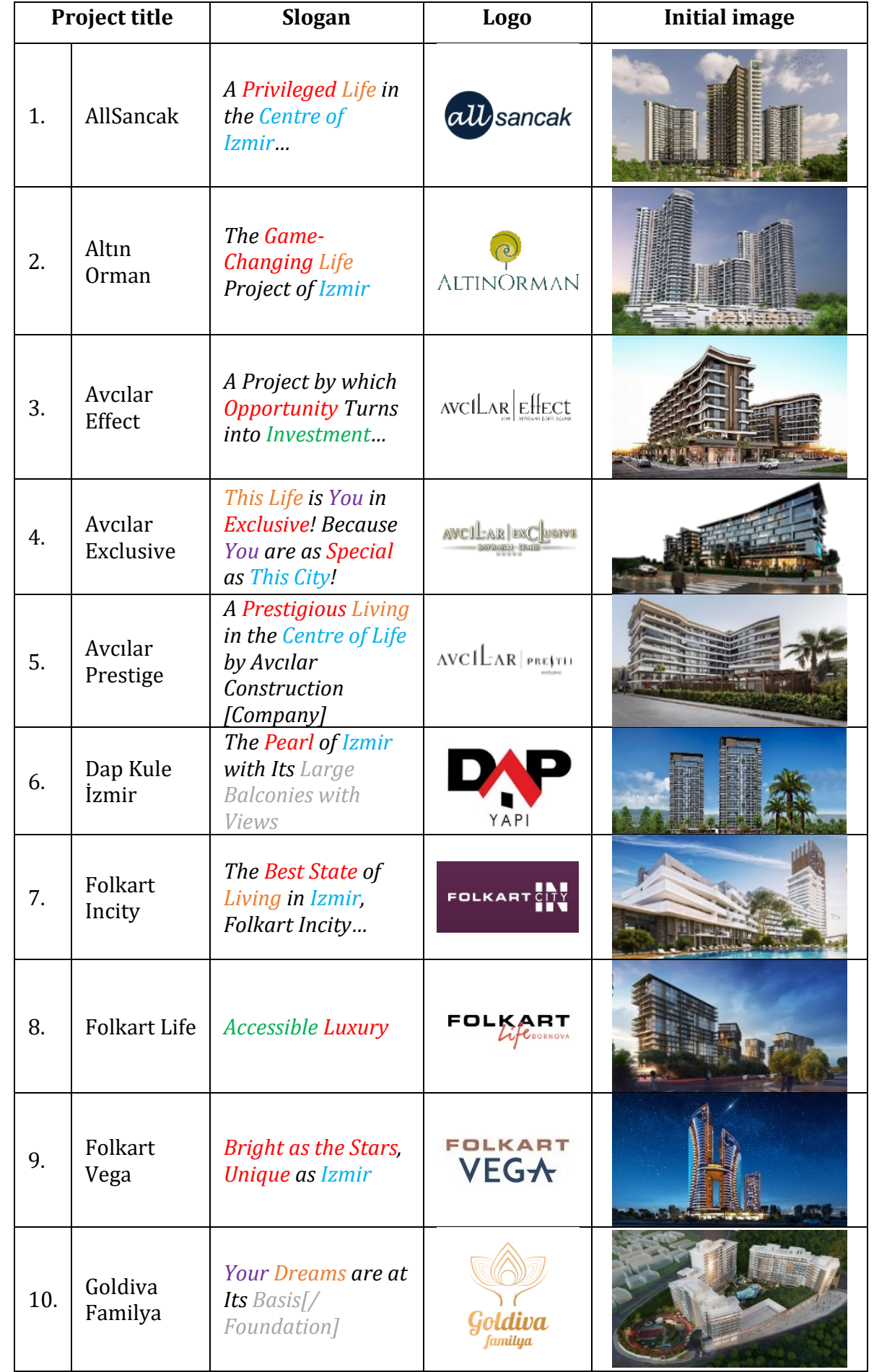


Examination of Prestigious Mass-Housing Identity via The Slogans: Cases in Izmir, Turkey

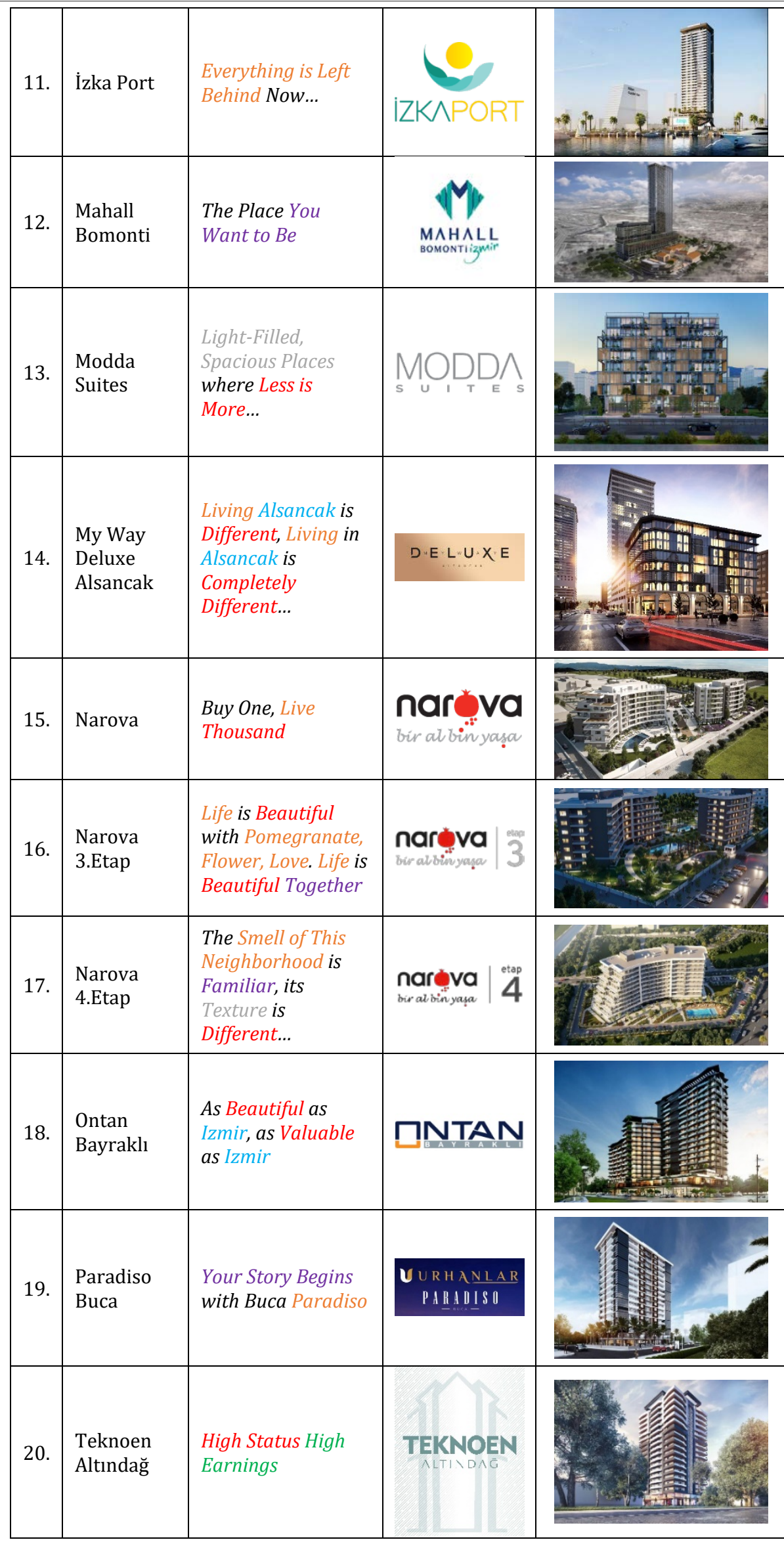


Table 4. Analyses of the direct and indirect messages in the slogans

\begin{tabular}{|c|c|c|c|c|c|c|c|}
\hline & 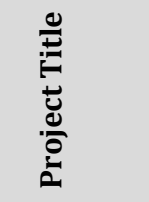 & $\underset{\tilde{E}}{\stackrel{n}{\pi}}$ & 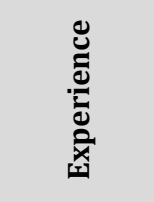 & : & $\begin{array}{l}\text { के } \\
\frac{0}{0} \\
\frac{2}{0} \\
\text { के }\end{array}$ & 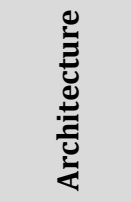 & 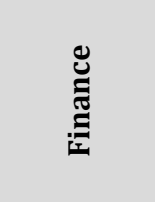 \\
\hline 1 & AllSancak & Privileged & Life & $\begin{array}{l}\text { Centre of } \\
\text { Izmir }\end{array}$ & - & - & - \\
\hline 2 & $\begin{array}{l}\text { Altın } \\
\text { Orman }\end{array}$ & $\begin{array}{l}\text { Game- } \\
\text { Changing }\end{array}$ & Life & Izmir & - & - & - \\
\hline 3 & $\begin{array}{l}\text { Avclar } \\
\text { Effect }\end{array}$ & $\begin{array}{c}\text { Opportunit } \\
y\end{array}$ & - & - & - & - & Investment \\
\hline 4 & $\begin{array}{l}\text { Avcilar } \\
\text { Exclusive }\end{array}$ & Special & This Life & This City & You & - & - \\
\hline 5 & $\begin{array}{l}\text { Avcllar } \\
\text { Prestige }\end{array}$ & Prestigious & Living & $\begin{array}{c}\text { Centre of } \\
\text { Life }\end{array}$ & - & - & - \\
\hline 6 & $\begin{array}{l}\text { Dap Kule } \\
\text { İzmir }\end{array}$ & Pearl & - & Izmir & - & $\begin{array}{c}\text { Large } \\
\text { Balconies } \\
\text { with } \\
\text { Views }\end{array}$ & - \\
\hline 7 & $\begin{array}{l}\text { Folkart } \\
\text { Incity }\end{array}$ & Best State & Living & Izmir & - & - & - \\
\hline 8 & $\begin{array}{l}\text { Folkart } \\
\text { Life }\end{array}$ & Luxury & - & - & - & - & Accessible \\
\hline 9 & $\begin{array}{l}\text { Folkart } \\
\text { Vega }\end{array}$ & $\begin{array}{c}\text { Bright as } \\
\text { the Stars; } \\
\text { Unique }\end{array}$ & - & Izmir & - & - & - \\
\hline $\begin{array}{l}\mathbf{1} \\
\mathbf{0}\end{array}$ & $\begin{array}{l}\text { Goldiva } \\
\text { Familya }\end{array}$ & - & Dreams & - & Your & $\begin{array}{c}\text { Basis [/F } \\
\text { oundatio } \\
n]\end{array}$ & - \\
\hline $\begin{array}{l}1 \\
1\end{array}$ & İzka Port & - & $\begin{array}{c}\text { Everything } \\
\text { is Left } \\
\text { Behind }\end{array}$ & - & - & - & - \\
\hline $\begin{array}{l}1 \\
2\end{array}$ & $\begin{array}{l}\text { Mahall } \\
\text { Bomonti }\end{array}$ & - & - & - & $\begin{array}{c}\text { You } \\
\text { Want to } \\
\text { Be }\end{array}$ & - & - \\
\hline $\begin{array}{l}1 \\
3\end{array}$ & $\begin{array}{l}\text { Modda } \\
\text { Suites }\end{array}$ & $\begin{array}{l}\text { Less is } \\
\text { More }\end{array}$ & $\begin{array}{l}\text { [Less is } \\
\text { More] }\end{array}$ & - & - & $\begin{array}{l}\text { Light- } \\
\text { Filled, } \\
\text { Spacious } \\
\text { Places; } \\
\text { [Less is } \\
\text { More] }\end{array}$ & - \\
\hline $\begin{array}{l}1 \\
4\end{array}$ & $\begin{array}{l}\text { My Way } \\
\text { Deluxe } \\
\text { Alsancak }\end{array}$ & $\begin{array}{c}\text { Different; } \\
\text { Completely } \\
\text { Different }\end{array}$ & Living & Alsancak & - & - & - \\
\hline $\begin{array}{l}1 \\
5\end{array}$ & Narova & Thousand & Live & - & - & - & - \\
\hline $\begin{array}{l}1 \\
6\end{array}$ & $\begin{array}{l}\text { Narova } \\
3^{\text {rd }} \text { stage }\end{array}$ & Beautiful & $\begin{array}{c}\text { Life; } \\
\text { Pomegran } \\
\text { ate, } \\
\text { Flower, } \\
\text { Love }\end{array}$ & - & Together & - & - \\
\hline
\end{tabular}


Examination of Prestigious Mass-Housing Identity via The Slogans: Cases in Izmir, Turkey

\begin{tabular}{|l|l|c|c|c|c|c|c|}
\hline $\mathbf{1}$ & $\begin{array}{l}\text { Narova } \\
\mathbf{7}\end{array}$ & Different & $\begin{array}{c}\text { Smell of } \\
\text { This } \\
\text { Neighbour } \\
\text { hood }\end{array}$ & - & Familiar & Texture & - \\
\hline $\begin{array}{l}\mathbf{1} \\
\mathbf{8}\end{array}$ & $\begin{array}{l}\text { Ontan } \\
\text { Bayraklı }\end{array}$ & $\begin{array}{c}\text { Beautiful; } \\
\text { Valuable }\end{array}$ & - & Izmir & - & - & - \\
\hline $\mathbf{1}$ & $\begin{array}{l}\text { Paradiso } \\
\text { Buca }\end{array}$ & - & Paradiso & - & $\begin{array}{c}\text { Story } \\
\text { Begins }\end{array}$ & - & - \\
\hline $\begin{array}{l}\mathbf{2} \\
\mathbf{0}\end{array}$ & $\begin{array}{l}\text { Teknoen } \\
\text { Altındag }\end{array}$ & $\begin{array}{c}\text { High } \\
\text { Status }\end{array}$ & - & - & - & - & $\begin{array}{c}\text { High } \\
\text { Earnings }\end{array}$ \\
\hline $\begin{array}{l}\text { Total times } \\
\text { of mention: }\end{array}$ & $\mathbf{1 6}$ & $\mathbf{1 3}$ & $\mathbf{9}$ & $\mathbf{6}$ & $\mathbf{4}$ & $\mathbf{3}$ \\
\hline
\end{tabular}

As seen in Table 4, in the status-based expressions, the concepts of opportunity, pearl, luxury, thousand; the adjectives of the privileged, gamechanging, special, prestigious, best state, unique, (completely) different, beautiful, valuable, and high status; and the phrases of bright as the stars, and less is more were used. Some of these terms denote metaphoric implications (pearl, thousand, game-changing, different, bright as the stars, and less is more) while the majority of them are direct messages about the social status to be gained (opportunity, luxury, privileged, special, prestigious, the best state, unique, beautiful, valuable, high status). However, this category has the highest frequency of references with 16 in total. In terms of the experience-based reading, the use of the words of life (4 times), living (3 times), and live (1 time) are seen frequently ( 8 times out of 13 mentions in total) with the implication to the importance of having a new living experience or lifestyle by the project. Besides, the metaphoric connotations by the use of the phrases such as everything is left behind, and less is more; and the concepts of nature (pomegranate, flower), feeling and sensory perception (dreams, love, smell of this neighbourhood, paradise) also point out the experience qualities provided by the cases.

In the psychology-based analysis, on the other hand, we see 4 references as implicit expressions by the word of you( $r$ ) per se; the adjective of familiar (for triggering the sense of belonging); the term of together (to connote the unity and love); and the phrases of [somewhere] you want to $b e$, and your story begins. In each of them, there is an emphasis on the importance of the personal and psycho-social preferences of the potential users. The urban qualities comprise the other strategies used in the marketing of the projects. Living in the centre mentioned directly and indirectly 3 times (centre of Izmir, centre of life, and Alsancak as the most popular neighbourhood in Izmir city-centre), having the accessibility of nature provided in the settlements while at the same time living in the city as mentioned 8 times (this city, and Izmir), and in this way, having the availability of the urban/social activities in the isolated environments keeping the crowds outside are the main foci points of the location-based references. 
Unfortunately, the architectural references are less in number (only 4 times in total). The phrases of large balconies with views, light-filled, spacious places, and texture [of the neighbourhood] are mentioned, while the personal dreams of the users are placed at the basis (also meaning foundation in Turkish) of the architectural project. Besides, the prominent motto of less is more by Ludwig Mies van der Rohe is directly quoted in one of the projects to imply both the experience- and statusbased gains of the potential users as well as pointing out the architectural understanding. However, as learned from the interviews with the designers, rather than showing a minimalist perspective, the motto was used with a misperception about its meaning to denote that the project provides the maximum status/comfort with a minimum investment/effort. Though not frequently used (3 times in total), the finance-based words demonstrate the intention to make the potential buyers think about their economic situations both now and in the future by mentioning the concepts of investment, accessible [luxury] (affordability), and high earnings.

In this analysis, it is obvious that all of the cases have different slogans, although the meanings and messages are similar. While some of them are stated overtly, some are pointed out covertly. In general, more than half of the projects promote the dream of a new and distinguished lifestyle in their slogans by giving reference to prestige or luxury with a promise of taking the lifestyle and living standards to the next level. But when the facilities are examined in Table 2, it is seen that the most preferred ones are outdoor swimming pool, café, fitness centre, site security, children's playground, car parking, sports fields, and indoor swimming pool, which are the services proposed for changing the lifestyles, and introducing the users with the high standards. Nevertheless, it is debatable how the users living in these gated mass-housing projects change their lifestyles by only using the outdoor and indoor swimming pools, living in a secure site, and parking their cars in a separate parking lot. When we also read the visual content of the projects (see Table 3) together with the verbal ones, the situation does not change: the emphasis is always on the facilities and services of which frequencies of use and need are debatable, too.

The logos in Table 3 are specially designed for the projects, though the design considerations are different. While all of them have stylistic fonts seen frequently in architectural representations, only three of them (Dap Kule İzmir, Mahall Bomonti, Teknoen Altındağ) contain architectural images-and one of which reflects directly the exterior façade of the project (Teknoen Altındağ). Like in the slogans, the other important theme, the urban identity of Izmir, is also considered in one of the logos (İzka Port), while the natural elements in the project settlement are demonstrated in three of them (Narova, Narova 3rd Stage, Narova 4th Stage). In these examples, we see that the main logo of the construction company was adapted according to the project by making minor changes following the theme of the project. The logos and the exterior design of the projects are very similar to each other as if they have been produced 
regarding other templates. Although housing is the oldest and most common architectural typology, it is very rare to see some references to high-quality solutions of architectural design, in different axes of promotional design. The architectural design per se is converted into a product and commodity to be consumed, and thus, having a price that symbolizes its owners' social statuses-though this fact is not frequently highlighted in promotional respect.

\section{CONCLUSIONS AND RECOMMENDATIONS}

The paper tries to figure out and analyse the relationships between the promotional strategies and architectural identities in the 20 masshousing cases produced for the high-income level, in Izmir city-centre, since 2015. Accordingly, all of the promotional strategies highlight the new and distinguished lifestyles to be obtained by having the product and services. Because of this wide consensus, the facilities provided in the settlements and housing blocks correspond to a template in terms of the promotional and architectural designs. The same services are sold with the same emphases in almost the same architectural envelops-high-rise blocks with smart technologies, and various indoor and outdoor facilities - the necessities of the majority are debatable.

In terms of figuring out the main layers of the promotional strategies that are planned to meet the luxury demands of the target user group, we may denote that they mainly comprise the status-, experience-, location-, psychology-, architecture- and finance-based dynamics. Nevertheless, the architectural qualities and settlement facilities/services imposed by the promotions may not correspond to the real needs of the inhabitants, since, for example, a library full of an insufficient number of books may not refer to the real expectation of the inhabitants. The idealist vision about meeting all the needs of inhabitants under the same complex is stemming from the basic disposition which had shaped the very first department stores - or shopping centres-of the industrialization period in the nineteenth century, under the influence of capitalist and consumerist dynamics. In this respect, we may even claim that the maintenance of this ideal, today, converts housing as the oldest architectural typology into an almost shopping centre based on marketing; the promise of meeting all needs under the same complex creates a new housing identity which can be called store housing (or shop housing) as a hybrid conception. The limitation coming from the isolation/gatedness in the city centre also increases the effect and feasibility of this store housing typology.

The prestigious mass-housing identity in Izmir since 2015 has been shaped by this template of store housing as echoed in the similar foci of the slogans and settlement services. The architectural template of each case is reflected in the promotional template of each case. Furthermore, it is seen that there is not an attempt of research in the housing sector to provide different cultures of living by the way of architectural design. Therefore, this research may also compensate for a lack related to the 
probable relationships between the architectural conceptions and promotional strategies in housing literature, propose a new basis for the theoretical readings of housing studies in Turkey, and point out the importance of setting a new design agenda to provide new cultures of living by suggesting new design solutions for the architectural offices. Not only for the high-income level but also for the rest of the society, alternative design proposals for indoor and outdoor spaces should be developed, progressed, and evaluated comparatively to enrich the experience quality in all of the housing projects.

In this respect, the mentioned architectural facilities (namely, the outdoor swimming pool, café, fitness centre, site security, children's playground, car parking, sports fields, and indoor swimming pool) are undertaken as the frequently used symbols/layers of prestige or luxury, and they are especially linked to the experience- and status-based promotional approaches with a specific emphasis on the new and dream lifestyle. On the other hand, the slogans (verbal context) and promotional images (visual context covering the logos and 3D renders) producing the spatial atmosphere of the prestigious mass-housing projects are consistent with each other. They both help the actors shape the housing identity with the same emphases. One cannot find a facility that is mentioned in verbal and visual respects in the catalogues/websites but is not provided in reality, in the housing settlement. Furthermore, when the practices of marketing and architecture intersect on a template, it has the potential of shaping the residential identity. This intersection per se is the identity of housing in most of the cases, for the cases refer to the overly adopted hybrid identity of the current prestigious mass-housing which is to be called store housing inviting the consumers to a continuous shopping while inhabiting, which will demonstrate their social status based on economic levels and sustain it by the emphasis on elitism/prestige.

Based on the outcomes of this study, it may also be examined whether there is the same problematic situation in the housing projects addressing different income groups. Besides different housing typologies may be analysed within a similar approach, and what kind of results can be obtained in different geographies may also be investigated. Some further evaluations may be provided by the questionnaires conducted with the inhabitants, and a review may be constructed by interviewing with the local government representatives. However, it is most probable that, in all of these further researches, the strength of the unifying power of the consumer society will continue to be manifested in both the architectural and promotional faces of the consumption culture-though, for sure, there will also be attempts to see the problems and seek for the alternative design-solutions to provide rooms for different preferences and lifestyles of the inhabitants, to break the templates with the unusual architectural and promotional qualities. 
Examination of Prestigious Mass-Housing Identity via The Slogans: Cases in Izmir, Turkey

FINANCIAL DISCLOSURE

The authors declared that this study has received no financial support.

\section{ETHICS COMMITTEE APPROVAL}

Ethics committee approval was not required for this article.

\section{LEGAL PUBLIC/PRIVATE PERMISSIONS}

In this research, the necessary permissions were obtained from the relevant participants (individuals, institutions, and organizations) during the survey and in-depth interviews.

\section{REFERENCES}

AllSancak. (2021, April 28). AllSancak E-Katalog. https://www.allsancak.com/katalog.php

Altaş Esin, N., \& Özsoy, A. (1998). Spatial Adaptability and Flexibility as Parameters of User Satisfaction for Quality Housing. Building and Environment, 33(5), 315-323.

Altın Orman. (2021). Altın Orman E-Katalog. https://www.altinorman.com.tr/themes/altinormanv1/assets/files/ka talog-2019-v4.pdf

American Marketing Association (AMA). (1985). Marketing. https://www.ama.org/the-definition-of-marketing-what-is-marketing/

Avclar Effect. (2021). Avcrlar Effect website. https://avcilarinsaat.com.tr/avcilar-effect

Avcılar Exclusive. (2021). Avcllar Exclusive website. https://avcilarexclusive.com/

Avclar Prestige. (2021). Avcllar Prestige website. https://avcilarinsaat.com.tr/avcilar-prestij-exclusive/

Baudrillard, J. (1998). The Consumer Society. Sage.

Baudrillard, J. (2002). Selected Writings. Stanford University Press.

Bauman, Z. (2000). Liquid Modernity. Polity Press.

Berry, C. J. (1994). The Idea of Luxury: A Conceptual and Historical Investigation. Cambridge University Press.

Bilgin, İ. (1994). "Siradan" Olanın Yeniden-Üretimi ve Konut Sorunu.

Bilgin, İ. (1996). Housing and Settlement in Anatolia in the Process of Modernization. In Y. Sey (Ed.), Housing and Settlement in Anatolia a Historical Perspective (pp. 472-490). History Foundation Publications.

Bilgin, İ. (2002). Türkiye'de Toplu Konut Üretimi ve Mimarlık. Arkitera. https://v3.arkitera.com/v1/platform/konut/ihsanbilgin2.htm

Blakely, E. J., \& Snyder, M. G. (1997). Divided We Fall: Gated and Walled Communities in the United States. In N. Ellin (Ed.), Architecture of Fear (pp. 85-99). Princeton Architectural Press.

Blandy, S., \& Lister, D. (2005). Gated Communities: (Ne)Gating Community Development? . Housing Studies, 20(2), 287-301. 
Bocock, R. (1993). Consumption. Routledge.

Bourdieu, P. (1984). Distinction: A Social Critique of the Judgement of Taste. Harvard Univ. Press.

Castells, M. (1983). The City and the Grassroots. Edward Arnold.

Chuon, A., Hamzah, H., \& Sarip, A. G. (2017). Conceptualising Luxury Residential Property for Marketing. Geografia Malaysian Journal of Society and Space, 13(2), 33-43.

Dap Kule İzmir. (2021). Dap Kule İzmir website. https://dapyapi.com.tr/dap-izmir

Debord, G. (2002). The Society of the Spectacle. Hobgoblin Press.

Dunleavy, P. (1980). Urban Political Analysis. Macmillan.

Es, M., \& Akın, Ö. (2008). Konut Memnuniyeti. Yerel Siyaset Dergisi, 25, 74-80.

Fabi, V., Andersen, R. V., Corgnati, S. P., \& Olesen, W. (2012). Occupants' Window Opening Behaviour, A Literature Review of Factors Influencing Occupant Behaviour and Models. Building and Environment, 58, 188198.

Featherstone, M. (2007). Consumer Culture and Postmodernism. Sage Publications.

Feigenbaum, A. V. (1991). Total quality control. McGrawHill.

Folkart Incity. (2021). Folkart Incity website. http://folkartincity.com/?AspxAutoDetectCookieSupport=1

Folkart Life. (2021). Folkart Life website. http://folkartlifebornova.com/

Folkart Vega. (2021). Folkart Vega website. https://folkartvega.com/

Goldiva Familya. (2021). Goldiva Familya website. http://www.goldivafamilya.com.tr/

Hasol, D. (2005). Ansiklopedik Mimarlık Sözlüğü. YEM Publications.

İzka Port. (2021). İzka Port E-Katalog. http://www.izkaport.com/

Keleş, R. (1998). Toplu Konut [Mass-housing]. In Kentbilim Terimleri Sözlüğü [Dictionary of Urbanology Terms]. İmge.

Keyder, Ç. (2006). Enformel Konut Piyasasından Küresel Konut Piyasasına. In İstanbul - Küresel ile Yerel Arasında. Metis.

Kotler, P., \& Keller, K. L. (2006). Marketing Management. Prentice Hall.

Kuru, O. N. (2021). Effects of Marketing Strategies on Prestigious Housing Identity: a Study on Mass-Housing Examples in Izmir City Center. Master Dissertation, Yaşar University.

Kwan, V. S. Y., John, O. P., Kenny, D. A., Bond, M. H., \& Robins, R. W. (2004). Reconceptualizing Individual Differences in Self-Enhancement Bias: An Interpersonal Approach. Psychological Review, 111(1), 94-110.

Lee, K. C., \& Young, P. F. (1996). Condominium dwellers: A study of lifestyle, profiles and condominium characteristics and attributes. Kinabalu Journal of Business and Social Sciences, 2(1), 17-32. 
Examination of Prestigious Mass-Housing Identity via The Slogans: Cases in Izmir, Turkey

Mahall Bomonti. (2021). Mahall Bomonti website. https://www.mahallbomontiizmir.com/

Modda Suites. (2021). Modda Suites website. https://www.moddasuites.com/

My Way Deluxe Alsancak. (2021). My Way Deluxe Alsancak website. http://www.mywaydeluxe.com/

Narova. (2021). Narova E-Katalog.

https://narova.com.tr/etap5/narovakatalog-etap5.pdf

Narova 3rd Stage. (2021). Narova 3rd Stage E-Katalog. https://narova.com.tr/etap3/narovakatalog.pdf

Narova 4th Stage. (2021). Narova 4th Stage E-Katalog. https://narova.com.tr/etap4/narovakatalog-etap4.pdf

Nicolae, P. A., Ioan, F. Ş., Florin, M., \& Liviu, P. N. (2009). A holistic approach of relationship marketing in launching luxury new products case study: research of the demand for housing in residential complexes in Oradea. In Annals of the University of Oradea, Economic Science Series (Vol. 18, pp. 808-813).

Ontan Bayraklı (2021). Ontan Bayrakll website. https://ontanbayrakli.com/

Öymen Gür, Ș. (2000). Doğu Karadeniz Örneğinde Konut Kültürü. . YEM Publications.

Özgüven, U. (2008). İstanbul'daki Lüks Konutların İncelenmesi ve Farklı Tiplerinin Karşılaştırılması. Master Dissertation, Istanbul Technical University.

Özüerken, Ş. A. (1996). Cooperatives and Housing Production. In Y. Sey (Ed.), Housing and Settlement in Anatolia a Historical Perspective (pp. 355-365). History Foundation Publications.

Paradiso Buca. (2021). Paradiso Buca website. http://www.urhanlarparadiso.com

Pickvance, C. (1985). The rise and fall of urban movements and the role of the comparative analysis. Environment and Planning. D. Society and Space, 3(1), 31-53.

Saunders, P. (1990). A Nation of Home Owners. Unwin Hyman.

Sey, Y. (1984). To House the New Citizens: Housing Policies and MassHousing. In R. Holod \& A. Evin (Eds.), Modern Turkish Architecture (pp. 159-183). University of Pennsylvania Press.

Sey, Y. (1994). Konutta Kalite ve Maliyet. In T. Aktüre (Ed.), Konutta Kalite. Mesa.

Slater, D. (1997). Consumer Culture and Modernity. Polity Press.

Teknoen Altındağ. (2021). Teknoen Altındağ E-Katalog. http://teknoen.com.tr/dergi/

Urry, J. (1995). Consuming Places. Routledge.

Warde, A. (1991). Gentrification as Consumption: Issues of Class and Gender. Environment and Planning D. Society and Space, 9(2), 223-232. 
Willis, P. E. (1990). Common Culture. Open University Press.

\section{Resume}

Oğuzcan Nazmi Kuru received his B.Arch. from Izmir University of Economics and M.Sc. from Yaşar University in the major of architecture. He currently studies on housing design quality and mass-housing, and works at Nezih Architectural Office as an architect.

Fatma Ipek Ek attained her B.Arch., M.Sc., and Ph.D. from Izmir Institute of Technology in the major of architecture. She published on housing design in Turkey, and the architectural design quality in mass-housing. She currently works at Yaşar University, Department of Architecture, as an academician. 